\title{
Inclusion in crisis response, recovery and resilience
}

Becky Carter

Institute of Development Studies

14 May 2021

\section{Question}

Provide a range of examples from the evidence on what has worked to ensure people affected by crises who experience heightened vulnerability due to social inequalities and discrimination (relating to gender; age; disability; sexual orientation, gender identity and/or expression, and sex characteristics; and religious belief) are included in crisis response, recovery and resilience.

\section{Contents}
1. Summary
2. Prevention
3. Participation
4. Resilience
5. Relief/services
6. References

The K4D helpdesk service provides brief summaries of current research, evidence, and lessons learned. Helpdesk reports are not rigorous or systematic reviews; they are intended to provide an introduction to the most important evidence related to a research question. They draw on a rapid deskbased review of published literature and consultation with subject specialists. other Government departments, but the views and opinions expressed do not necessarily reflect those of FCDO, the UK Government, K4D or any other contributing organisation. For further information, please contact helpdesk@k4d.info. 


\section{Summary}

This rapid review provides examples of what has worked to include people in humanitarian assistance who experience heightened vulnerability during crises, due to social inequalities and discrimination relating to gender, age, disability, sexual orientation, gender identity and/or expression, and sex characteristics; and religious belief ${ }^{1}$. Overall, robust evidence is limited for what are, in most cases, relatively new areas of practice in challenging crisis situations. However, the literature does identify promising practices. Emerging themes from the research on what has potential for improving inclusion in humanitarian assistance include: affected people's meaningful participation in intervention planning and design; whole-of-community approaches while maintaining accountability to the targeted beneficiaries; multi-component approaches combining complementary strategies (e.g. economic empowerment with social norms change programming); longer-term, pre-crisis investment in relationships with, and capacity building of, local organisations; and disaggregating data and undertaking intersectional analyses to include those hardest to reach.

\section{Review focus, scope and structure}

Undertaken in nine days through searching online for English language materials, the report covers interventions in response, recovery and resilience for severe humanitarian events such as conflicts, disasters, pandemics and food crises. This is not a comprehensive evidence review; the evidence is an illustrative selection identified in the time allowed. The report has prioritised evidence from the last five years but has included some useful older literature. It has focused on evidence on "what has worked"; in some cases challenges and other issues are included to enable fuller understanding of an intervention's effectiveness (and limitations).

This report seeks to provide an insight into the overall standard and range of evidence available, drawing on systematic or rigorous evidence reviews where available, to provide the context by which to understand the examples of evidence included. This review does not assess the quality of evidence. It refers to peer reviewed literature and formal independent evaluations where available. However, given the lack of robust detailed data and analysis for many of the intervention areas and forms of marginalisation, the report also includes grey literature, such as case studies produced by non-governmental organisations (NGOs) and evidence summaries by think tanks. The report also signposts examples of best practice guidance produced by donors and UN organisations; it does not provide a comprehensive list of all guidance available and nor does it summarise all of the principles and recommendations.

The report has organised evidence on four areas of humanitarian assistance - prevention, participation, resilience and relief/services. These areas are related with some overlap while interventions tend to have multiple components and outcomes pertaining to more than one area.

\section{Evidence base}

Overall a key theme in the literature is that while there has been growing awareness of the importance of inclusive humanitarian assistance, there is still relatively limited systematic programming experience, and even scarcer robust evidence of effectiveness. The review has

\footnotetext{
${ }^{1}$ A companion helpdesk report summarises the evidence on the impact of social inequalities and discrimination on vulnerability to crises (Carter, 2021).
} 
found more examples, and more evidence of their effectiveness (including a limited number of rigorous impact and experimental evaluations), for interventions seeking to support women and girls in humanitarian assistance, than for other groups. The report reflects this imbalance while deliberately including some of the more descriptive accounts of inclusion of people affected by other forms of discrimination, to give examples of the type of evidence available across all areas. This rapid review found the least evidence on crisis interventions seeking to include people affected by discrimination for their sexuality or their religion. There are also few interventions operationalising the growing appreciation that drivers of inequalities are intersectional, and little evidence on their effectiveness (Barbelet \& Wake, 2020: 28). Moreover the evidence base for humanitarian interventions supporting women and girls still has gaps: the evidence tends to be designated promising rather than effective (that is, based on a limited number of impact and programme with/out control/comparison groups in a limited number of contexts) (Murphy et al., 2019: 17). In addition, most of the evidence is from protracted crises and refugee settings, with gaps in knowledge for what works in the more acute emergency phases of crises.

\section{Key findings}

\section{Prevention:}

- "Community-based programming on attitudes, behaviours and social norm change addressing violence against women and girls shows promise" in humanitarian and conflict settings (Murphy et al., 2019: 17). Recent innovative models incorporate economic empowerment or livelihoods programmes with social norms change programming.

- There is limited evidence of the positive impact at a country level of central United Nations human rights norm setting (and the various associated accountability activities); this is a contentious, complex area of debate and it is highly challenging to establish causality.

- Good practices in gender and security sector reform include holistic, multisectoral approaches that are context-specific and locally owned, and engage with informal justice providers (DCAF et al., 2019b). There are reports of positive experiences with mobile courts and community paralegals increasing access to justice for women and girls with disabilities.

\section{Participation}

- Adolescent girl focused empowerment programmes in crises have improved girls' lives (through increased life skills, social networks and economic opportunities), and in some cases helped reduce their experiences of physical violence, early marriage, and early pregnancy (Violence Against Women and Girls (VAWG) Helpdesk, 2020; Bourassa \& Murphy, 2020; Murphy et al., 2019). Successful strategies include multi-component approaches working with the wider community and providing safe spaces. Including girls with disabilities in adolescent girls programming can mitigate their risk of violence and abuse (Women's Refugee Commission (WRC), 2015).

- There is slow progress, and little robust evidence, on interventions supporting the meaningful participation of local organisations of people affected by social inequalities in humanitarian responses. Key lessons from working with humanitarian age and disability task forces are to engage with organisations of people with disabilities and older people before a crisis; embed task forces in existing humanitarian coordination structures; and dedicate time and resources to sensitise humanitarian actors on disability and inclusion (Palmer et al., 2019: 51-52). Meanwhile faith organisations can respond rapidly and effectively in emergencies, drawing on widespread networks to mobilise resources, staff and volunteers (Wilkinson et al., 2016). 
- There is strong evidence on the role of women in inclusive peace processes; international actors can help support women's collective action and address practical and structural constraints to women's voice and leadership (Birchall, 2020). There is growing interest in youth participation in peace processes, with some positive case studies; a youth lens can be enhanced by taking into account other drivers of inequalities (e.g. gender, religion)

(Paaskesen \& Martial Ouakouma, 2020).

\section{Resilience}

- Preparedness and disaster risk reduction (DRR): community Disaster Management Committees can be sustainable forums to include people with disabilities in decision-making (Palmer et al., 2019). Integrating mental health and psychosocial support with DRR interventions can build resilience for groups who may be vulnerable to mental health and psychosocial issues during crises, and include people with more profound mental health problems and psychosocial disabilities in DRR practices (Inter-Agency Standing Committee (IASC), 2021).

- Promising practices on supporting girls' education in emergencies, including for girls with disabilities, involve sustainable, flexible interventions that enable new behaviours and norms, while involving girls and communities in intervention planning to address barriers to continuing in school. Gender-responsive distance education provision, of growing interest since COVID19 related school closures, have the potential to increase education access for children with disabilities and reach out-of-school children. (Guglielmi et al., 2021)

- Livelihoods interventions require gender and gender-based violence analysis to understand possible threats and violence an intervention may trigger (Young Lee, 2014). Experience of supporting livelihoods programming to be inclusive of people with disabilities highlights the need to 1) disaggregate indicator targets by sex, age and disability to reach people with disabilities more at risk of exclusion, and 2) allow time to overcome attitudinal barriers and reach many people with disabilities affected by low levels of education and self-confidence (Palmer et al., 2019).

- Additional support is required to ensure humanitarian cash transfers are inclusive of older people and people with disabilities (Juergens \& Galvani, 2020; Brown \& Rothe, 2020). Cash plus interventions providing linkages to complementary services and referrals are promising approaches for ensuring continuity of girls' learning in emergencies (Guglielmi et al, 2021). There is limited evidence and mixed findings on the potential of cash transfers to empower women's decision-making and reduce gender-based violence in humanitarian contexts.

\section{$\underline{\text { Relief/services }}$}

- Inclusive data and analysis: Gender analyses in humanitarian emergencies have successfully improved inclusive humanitarian response (Huxtable \& Gillingham, 2020). Emerging examples show data disaggregation can help direct support to people affected by other, and intersecting, drivers of marginalisation including disability and sexuality.

- There are promising experiences of inclusion in community-based services, such as supporting gender-based violence service providers to include people with disabilities, and women with disabilities and caregivers in village savings and loans groups, in conflict-affected communities (Pearce, 2015). Inclusive community engagement has worked when programmes to prevent violence against women and girls in crises apply an 'all-of-community' approach, while ensuring programmes are centred on, and accountable to, the women and girls (Murphy et al., 2019). 
- Qualitative research highlights cases where targeted/specialised services during crises for people facing discrimination have worked, including mobile gender-based violence services in hard-to-access humanitarian settings (James et al., 2018); support for male survivors of sexual and gender-based violence on the Mediterranean refugee/migrant route (Chynoweth, 2019); and support for trans women refugees in Lebanon (WRC, 2021).

\section{Prevention}

This section looks at what has worked to prevent people affected by social inequalities and discrimination from being exposed to harm ("protection threats"), including violations of international humanitarian and human rights law, during humanitarian crises (IASC, 2016). It focuses on three areas: transforming social norms in crises; increasing accountability and promoting human rights in crises; and inclusion in security sector reform.

\subsection{Transforming social norms in crises}

Recently there has been growing interest in prevention programmes in crisis settings that seek to address discriminatory social norms, particularly in relatively settled refugee or displacement contexts (Murphy \& Bourassa, 2021: 38). Most of the literature is on interventions targeting harmful gender norms that underpin gender-based violence ${ }^{2}$, with more limited evidence on prevention activities in crisis contexts engaging with other social norms. Examples include norms underpinning stigma and prejudice towards people with disabilities; the relationship between prevailing masculinities and conflict more generally; and religions and conflict.

Common strategies for addressing harmful gender norms in humanitarian contexts include:

1) community discussions facilitated by community leaders, peers and other change agents;

2) media (radio, films, podcasts, drama/theatre skits); 3) empowering participatory approaches; and 4) engaging men to develop skills to "resolve community and relational conflict" (Murphy \& Bourassa, 2021: 39). Effectiveness evidence on this relatively new experience of implementing community-based social norms change interventions in crisis contexts remains limited; few evaluations have been completed, with "none during more acute phases of emergencies" (Murphy et al., 2019: 17). However, the 2019 evidence synthesis by the What Works to Prevent Violence Against Women and Girls programme was able to conclude that "Community-based programming targeting attitudes, behaviours and social norms change shows promise ${ }^{3 "}$ in humanitarian and conflict settings (Murphy et al., 2019: 17). The literature also highlights that there are limited resources available for these longer-term gender-based violence prevention programming modalities and research on their effectiveness (Murphy \& Bourassa, 2020: 66).

\footnotetext{
2 Gender-based violence (GBV) is "an umbrella term for any harmful act that is perpetrated against a person's will and that is based on socially ascribed (i.e. gender) differences between males and females. It includes acts that inflict physical, sexual or mental harm or suffering, threats of such acts, coercion and other deprivations of liberty. These acts can occur in public or in private." (IASC, 2015: 5)

${ }^{3}$ Murphy et al. (2019: 17) define interventions as "promising" when there are "impact and programme evaluations (including those without comparison or control groups) available in a limited number of contexts demonstrating change on key outcomes". They classify interventions as "effective" when there are "impact evaluations (experimental and quasi-experimental designs) available in a wide variety of contexts demonstrating change on key outcomes".
} 
Examples from the evidence of what has worked

- School peace education and community social norms change intervention in Afghanistan: This intervention aimed "to change harmful social norms and practices related to gender and the use of violence in conflict resolution, ... with the aim of reducing violence against and between children", working with children in schools, and parents and other stakeholders including community and religious leaders, civil society organisations and influential women (government officials and human rights activists). An interrupted time-series evaluation found significant reductions for both boys and girls in peer violence; corporal punishment by teachers; physical punishment at home; and observing family violence at home. Moreover, girls' school attendance improved. Limitations of the research include that it did not separate out the impact of the different activities of this complex multi-component intervention. (Corboz et al., 2019)

- UNICEF "Communities Care" programme to address violence against women and girls in Somalia and South Sudan: Cited as a good practice example of a communitybased approach to preventing and responding to violence against women and girls (Violence Against Women and Girls (VAWG) Helpdesk, 2020: 4), this approach combines "strengthening of formal \& informal community-based multi-sectoral response services, through addressing social norms reflected by service providers and institutions" with "community engagement \& action for prevention using a social norms perspective" (Perrin et al., n.d.). An impact evaluation of a longitudinal randomised community-based trial of programme pilots in conflict-affected communities in Somalia and South Sudan found "sustained positive impacts on personal beliefs and changes to social norms around [gender-based violence] among those exposed to the programme" (Murphy \& Bourassa, 2021: 39, citing the original study).

- Transforming harmful norms on disability in Kenya: The Kenya Red Cross Society focused on demystifying disability through community and household awareness-building and advocacy activities, and sensitizing local authorities. Community health workers visited households with people with disabilities and shared information. As a result, "older people and people with disabilities had improved access to humanitarian services. Community support groups of people with disabilities have been formed to offer peer help and emotional support to people with disabilities" and "are now linked with the community health workers and Red Cross response teams". (Akerkar \& Bhardwaj, 2018: 92-93)

- Preventing inter-religious violence in Plateau State, Nigeria: A 2012 mixed methods evaluation investigated a US Department of State's Bureau for Democracy, Human Rights and Labor funded programme implemented by Search for Common Ground since 2011 in a region experiencing violent Muslim-Christian clashes. Programme activities involved leadership training; collaborative community dialogues; various community interventions; and peace radio programming. The evaluation found the programme had a positive impact on the process of inter-religious, intercommunity dialogue for peace, with study informants reporting changed attitudes, skills and behaviour, with increased understanding of the complexities of conflict and willingness to build "new relationships with and a deeper understanding of people from the opposite religious group". (Ashton, 2013: 8-9, 19) 


\subsection{Increasing accountability and promoting international humanitarian law and human rights norms in crises}

International human law and inter-governmental bodies such as the United Nations (UN) Human Rights Council and Security Council constitute an international accountability system for promoting and upholding human rights during crises. These bodies "generally have a supervisory or oversight role rather than enforcement function", and are seen to "play an important role in requiring States to justify their development performance in the light of human rights principles ... and issue recommendations for strengthening domestic accountability" (Office of the High Commissioner for Human Rights (OHCHR) \& Center for Economic and Social Rights (CESR), 2013: xi). For example, OHCHR and CESR (2013: 50) finds that "The procedures of the Human Rights Council provide a degree of international political accountability, notably through its universal periodic review (UPR), but also through resolutions on topical and emerging human rights issues, and through the work of the special procedures mandate holders it appoints." They play a particularly valuable role for groups that are not listened to by their own governments (OHCHR \& CESR, 2013: xi.).

However, the literature highlights that reaching firm conclusions on how international humanitarian law and human rights norms policy and initiatives arising from central UN bodies go on to impact country level change is very difficult, given the complexity of issues involved and challenges to establishing to causality. Moreover, with "grave" and "systemic" failures of the UN response to events in Sri Lanka in 2009 (Petrie, 2012), the OHCHR and UN High Commissioner for Refugees (UNHCR) (2013: 2) notes that the international community "continues to grapple with the challenge of ensuring the full realisation of human rights during humanitarian crises"; when, how and who should intervene in the case of atrocity crimes and gross human rights violations continue to be highly contentious issues.

\section{Examples from the evidence of what has worked}

- Hald et al. (2021) explores how agreed normative frameworks on inclusivity in peace and development are implemented at the country-level by the UN, looking in particular at the inclusion of women and youth. Two positive examples are: (Hald et al., 2021: 60-61)

- "In 2018 the UN was able to use the Human Rights Council's Universal Periodic Review (UPR) process, and its outcome, to engage civil society and raise normative issues with the Jordanian Government. The UN's efforts in November 2018 at bringing together national and international CSOs and government for an in-country pre-session during the UPR process was raised as a case of good practice in providing safe spaces for sensitive conversations."

- "UN Security Council Resolution 1325 was described by interviewees as a useful tool to mobilise both resources and women's engagement, as it legitimises the work already being done by a number of women-led CSOs in the country. Through a collaboration with UN Women, UNDP and the [Jordan National Committee for Women], CSOs have been able to access global funding for the promotion of Resolution 1325, which helped in realising the creation of the [National Action Plan on implementing Resolution 1325)." 
- In 2015, the global review of the implementation of UN resolution 1325 on women and peace and security ${ }^{4}$ highlighted positive progress since adoption of the resolution in 2000, including: (Coomaraswamy, 2015: 13)

- international community's adoption of a comprehensive normative framework for sexual violence in conflict;

- development of international jurisprudence in international courts and tribunals;

- appointment of a Special Representative on Sexual Violence in Conflict;

- establishment of a local level monitoring and reporting mechanism reporting to the Security Council; and

- Human Rights Council commissions of inquiry and fact-finding missions increasingly mandated to investigate sexual and gender-based violence, with a roster of international experts to support investigation of these crimes.

However, there had been few prosecutions on sexual violence at the national level, leading some to "claim that there has been no significant difference for women on the ground" (Coomaraswamy, 2015: 14). Moreover, despite "a great deal of rhetoric supporting women, peace and security, funding for programmes and processes remains abysmally low", accounting for "only two per cent of aid earmarked for peace and security" (Coomaraswamy, 2015: 14-15).

- Schaaf et al (2020: 1) examine the accountability strategies "employed to address the availability, accessibility, acceptability, and quality of [sexual and reproductive health services (SRHs)] in humanitarian settings" (noting that SRHs are related to numerous human rights ${ }^{5}$ ). They find that a "universal architecture" of international human rights law, professional principles, and minimum standards provides accountability for policymaking and programme design and implementation (Schaaf et al., 2020: 13). They identify four categories of approaches to accountability: "(1) humanitarian principles, codes of conduct, and legal instruments; (2) technical, performance, and impact standards; (3) efforts to solicit and address the rights and needs of the affected populations, or "listening and responding," and, (4) accountability demands made by affected populations themselves" (Schaaf et al., 2020: 2). However, they find that "institutional commitment to implementation, robust mechanisms to ensure implementation, and sanctions and access to remedy in the case of failure remain major gaps" (Schaaf et al., 2020: 13). Promising accountability approaches identified included open and close-ended feedback from affected populations and practical application of standards for performance accountability (Schaff et al., 2020: 13).

- In her evidence review, Haider (2016: 5) finds that international humanitarian provisions and actions can be "an entry point to subsequent discussion of ceasefires, security and political issues, and peace talks between the government and rebel groups", for example "in Darfur, Sudan (2003), where formal agreements on humanitarian issues paved the way for talks on security or political issues" and "in the Philippines (2009), where a formal agreement to improve the protection of civilians in armed conflict was believed to support

\footnotetext{
${ }^{4}$ https://www.unwomen.org/en/docs/2000/10/un-security-council-resolution-1325 [Accessed 10 May 2021]

5 "Women's sexual and reproductive health is related to multiple human rights, including the right to life, the right to be free from torture, the right to health, the right to privacy, the right to education, and the prohibition of discrimination." https://www.ohchr.org/en/issues/women/wrgs/pages/healthrights.aspx [Accessed 10 May 2021]
} 
peace talks between the Government and the Moro Islamic Liberation Front" (Haider, 2016: 4, citing various studies).

- Chynoweth et al. (2018) look at how interpersonal accountability "imposed through shared professional norms and robust, transparent coordination platforms" among humanitarian aid workers following Cyclone Nargis in Myanmar in 2008 and the Haiti earthquake in 2010 "may be an important complement to principles and codes of conduct ... In other words, shared norms among humanitarian workers; facilitative behaviors, such as communication, acknowledging and addressing mistakes, and constructive criticism; and rewards, can help to promote the realization of principles and codes of conduct." (Schaaf et al., 2020: 8, summarising findings from Chynoweth et al, 2018)

\subsection{Inclusion in security sector ${ }^{6}$ reform}

Inclusion is a central objective of security sector reform as encapsulated by the 2020 Sustainable Development Agenda (SDG) to leave no one behind and "Promote peaceful and inclusive societies for sustainable development, provide access to justice for all and build effective, accountable and inclusive institutions at all levels" (SDG 167).

Literature on advancing gender equality and integrating a gender perspective in security sector reform has developed considerably in the last decade. Issues are multiple, ranging for example from the underrepresentation of women within security and justice institutions, which limits effective services across all parts of communities, to the need for specialised procedures and infrastructure for responding to gender-based violence (DCAF ${ }^{8}$ et al., 2019a). A 2020 Gender and Security Toolkit by DCAF, OSCE/ODIHR ${ }^{9} \&$ UN Women ${ }^{10}$ sets out detailed guidance, good practice and impact pathways for how to improve security and justice from a gender perspective. This toolkit highlights the need to prevent discrimination against people with diverse sexual orientation, gender identity and/or expression, and sex characteristics ${ }^{11}$. It also points out the need to take into account the intersectionality of discrimination, giving special consideration to ensuring access to justice for women and girls from "ethnic or religious minority groups, LGBTI"12, displaced, have disabilities, are illiterate or do not speak the official language(s) in a particular country" (DCAF et al., 2019b: 41). Drawing on good practices, the brief on gender and access to justice finds that a holistic, multisectoral approach offers the greatest potential, while any change effort needs to be "context-specific, inclusive, locally owned and openly communicated" (DCAF et al., 2019b: 30).

The evidence base for security and justice interventions is mainly observational, with few experimental studies, which leads Jackson et al. (2019:4) to conclude that "there is limited

\footnotetext{
6 The security sector involves multiple state and non-state actors as well as internal and external oversight and accountability mechanisms that provide safety, security and justice at different levels (Birchall, 2020).

7 https://www.un.org/sustainabledevelopment/peace-justice/ [Accessed 12 May 2021]

8 Geneva Centre for Security Sector Governance.

${ }^{9}$ Organization for Security and Co-operation in Europe/Office for Democratic Institutions and Human Rights.

10 https://dcaf.ch/gender-and-security-toolkit [Accessed 13 May 2021]

${ }^{11}$ https://dcaf.ch/gender-and-security-toolkit [Accessed 13 May 2021]

12 Lesbian, Gay, Bisexual, Trans, and Intersex.
} 
information on the effectiveness of [security and justice] interventions". From their evidence mapping, Jackson et al. (2019: 6) find that evidence on gender-specific justice and security interventions has increased in recent years but "there remains very little good quality data related to gender-based violence rates".

This rapid review found little research on what has worked in improving the barriers to effective security and justice experienced by people discriminated against for their age, disability, sexuality and/or religion. Looking at what was worked to improve justice for people with disabilities, while there is guidance ${ }^{13}$, and some grey literature on good practices (Flynn et al., 2019; Ortoleva, 2019), there is a lack of rigorous evidence. This was identified as a major gap by Saran et al.'s (2020) systematic evidence review. The literature highlights a scarcity of research on women with disabilities' access to justice, while "women with disabilities are disproportionately excluded from legal protection", facing attitudinal, physical, informational and financial barriers, a situation compounded again for women with disabilities who are members of minority groups (Ortoleva, 2019: 1-2).

\section{Examples from the evidence of what has worked}

- Access to justice for women in Liberia: implemented by ActionAid with local partners in three districts in the southeast of the country ${ }^{14}$, the project's success was driven by its holistic approach (Birchall, 2020: 10). The project increased awareness and understanding of women's rights; worked with the informal justice system and strengthening its capacity to deliver fair justice for women; and promoted the coordination of actors responding to violence against women (ActionAid., 2012: 9). Achievements included: (Birchall, 2020: 10, summarising UN Women et al., 2018: 99)

- $\quad$ "An increase in the number of women willing to access justice through the formal justice system.

- An increase in women's understandings of inheritance and rape laws, referral mechanisms for accessing justice, and UN resolutions 1325 and 1820.

- Setting up mediation groups, which train women in conflict mediation skills and provide informal level legal aid through the settling of domestic violence and domestic dispute cases in the community."

- Mobile courts supporting women with disabilities in Democratic Republic of Congo (DRC): Mobile courts, working with the state justice system, reached remote and rural areas in DRC, mitigating physical and financial barriers that women with disabilities face in attempting to access the larger, urban courts. Without these mobile courts, in these areas women with disabilities who were victims of sexual and gender-based violence

\footnotetext{
13 International Principles and Guidelines on access to justice for persons with disabilities: https://www.ohchr.org/EN/Issues/Disability/SRDisabilities/Pages/GoodPracticesEffectiveAccessJusticePersonsDi sabilities.aspx [Accessed 11 May 2021]

${ }^{14}$ This is part of a two-year, multi-country initiative "Access to Justice for Women" initiated in early 2009 by ActionAid (AA) and Women for Women International Nigeria (WfWI Nigeria) and funded by the UK's Department for International Development (DFID)/UK aid and the Danish Ministry of Foreign Affairs (Danida). The project focused on ensuring and increasing women's access to justice in conflict and post-conflict environments and was implemented in seven African states: Burundi, the Democratic Republic of Congo (DRC), Liberia, Nigeria, Sierra Leone, Somaliland and Uganda. (ActionAid, 2012: 5)
} 
may not have been able to access a courthouse. (Ortoleva et al., 2019: 6, citing several sources)

- Paralegals increasing access to justice for women and young people with disabilities in Uganda: As part of the National Union of Women with Disabilities' paralegal programme, "Thirty-two women with disabilities were trained about the rights of women and girls with disabilities relating to gender-based violence and sexual and reproductive health and rights. These paralegals became community role models, offering peer-to-peer support in reporting violations and conducting the necessary followup to ensure justice was achieved, and advocating for systemic change." (Ortoleva et al., 2019: 10)

\section{Participation}

The participation of communities and people affected by crisis in humanitarian aid is key to achieving inclusive, effective assistance ${ }^{15}$. This section looks at what has worked to achieve meaningful participation of people experiencing heightened vulnerabilities due to social inequalities and discrimination, in three areas: empowerment programmes; the role of local organisations; and peace processes.

\subsection{Empowerment programmes}

Empowerment - the ability of a person to control their own destiny ${ }^{16}$ - is considered an important principle of humanitarian action ${ }^{17}$. There has been a growing focus in humanitarian principles and guidance on the empowerment of people with heightened vulnerabilities due to social inequalities and discrimination. A broad set of interventions may have or be trying to achieve empowerment outcomes: some of these are described in more detail elsewhere in this report (for example, Section 4.2 on education and livelihoods interventions, Section 4.3 on social protection).

While still a relatively new focus of humanitarian assistance, most literature found by this rapid review is on interventions to empower women and adolescent girls in crises. There appears to be limited information on how common - or how effective - interventions with empowerment outcomes are in crisis contexts for people affected by other drivers of marginalisation (such as disability, age, religion, sexuality) (Holden et al., 2019: 9; Robinson et al., 2020).

\footnotetext{
${ }^{15}$ As set out by the Core Humanitarian Standard on Quality and Accountability, agreed by a global alliance of humanitarian and development organisations. https://corehumanitarianstandard.org/the-standard [Accessed 13 May 2021]

${ }^{16}$ The full definition of empowerment of women and girls provided by IASC (2017: 12) is: "Empowerment of Women and Girls refers to the ability of a woman or girl to control her own destiny. This implies that she must not only have equal capabilities (such as education and health) and equal access to resources and opportunities (such as land and employment), but that she must also have the agency to use these rights, capabilities, resources and opportunities to make strategic choices and decisions."

${ }^{17}$ For example, IASC has made "gender equality and the empowerment of women and girls a core principle of its humanitarian action” (IASC, 2017: 1).
} 
Two examples of evidence highlighted in the literature of what has worked in humanitarian empowerment programmes are on 1) empowering adolescent girls; 2) empowering women and girls to change experiences of gender-based violence.

Adolescent girls: There is growing guidance on humanitarian assistance to empower adolescent girls ${ }^{18}$ but little systematic programming and even less evaluation of impact. What evidence there is, tends to be from post-conflict or protracted crises (not active humanitarian emergencies), with no follow-up to check on long-term effect (VAWG Helpdesk, 2020: 3; Murphy \& Bourassa, 2021: 40; Boost et al., 2020). Emerging promising evidence shows that adolescent girl focused empowerment programmes, with life skills delivered along with other interventions supporting social networks, relationship-building and economic opportunities, can improve girls' lives (through improved life skills, attitudes) (VAWG Helpdesk, 2020; Bourassa \& Murphy, 2020: 40; Murphy et al., 2019: 17). There is also some promise of helping to reduce girls' experiences of physical violence, early marriage, and early pregnancy during emergencies (Boost et al., 2020, citing several studies); but life skills interventions "may not decrease experience of sexual violence" (VAWG Helpdesk, 2020: 5). Effective strategies highlighted by available evidence include multi component approaches working with the wider community, "and which combine safe spaces, with skills curricula, mentorship, and male and female parent-caregiver engagement" (VAWG Helpdesk, 2020: 3); and the provision of safe spaces to access relief, information, referral service and skills training, and develop social support networks ${ }^{19}$ (VAWG Helpdesk, 2020: 5; Robles, 2014: 1-2). WRC (2015: 4) notes the importance of making "safe spaces 'safe' for all girls", including girls with different types of disabilities.

Empowerment and gender-based violence: Women and/or girls' economic empowerment interventions, through livelihoods and/or skills training, are often deployed to "shift power dynamics", increase a woman's control over assets and income-generation, and thereby reduce gender-based violence (Murphy \& Bourassa, 2020: 40). However, randomised controlled trials and other evidence present mixed findings of the impact of economic empowerment on violence against women and girls in humanitarian and conflict contexts, with a risk that "as women take on more 'masculine' roles around providing for the family, they might also experience increased violence" (Murphy \& Bourassa, 2020: 40). Recent innovative models incorporate economic empowerment or livelihoods programmes with "wider social norms and behaviour change programming that addresses violent behaviour and the patriarchal social norms that normalise violence" (VAWG Helpdesk, 2020: 5; Murphy \& Bourassa, 2020: 40). So far most empirical evidence on these programmes is from post-conflict settings; acute emergency best practice is "less clear" (Murphy \& Bourassa, 2020: 40).

There is comparatively little research on interventions supporting the empowerment of girls with disabilities to reduce gender-based violence in humanitarian contexts. The Women's Refugee Commission has produced guidance for humanitarian actors drawing on positive field

\footnotetext{
18 VAWG Helpdesk (2020: 3) mentions the Women's Refuge Commission's tools and guidance on the "I'm here" approach to supporting adolescent girls throughout the humanitarian programming cycle, and ActionAid guidance on women and girl's leadership in their women-led community-based protection approach. VAWG Helpdesk (2020: 3) also lists significant guidance developed in the protection and empowerment of adolescent girls in regard to gender-based violence. See VAWG Helpdesk (2020: 3) for full details.

${ }^{19}$ For guidance on safe spaces for women and girls, the International Rescue Committee (IRC) and International Medical Corps (IMC) have co-created 'Safe Spaces: A Toolkit for Advancing Women's and Girls' Empowerment in Humanitarian Settings" (Megevand \& Marchesini, 2020).
} 
experiences on how to include girls with disabilities in adolescent girls programming, "mitigating their risk of violence, abuse and exploitation" (Pearce et al, 2016: 129).

\section{Examples from the evidence of what has worked}

- Empowering adolescent girls in Ethiopia, DRC and Pakistan: VAWG Helpdesk (2020

3) highlight that "A significant contribution to the evidence and best practice on multicomponent approaches in humanitarian contexts is IRC's COMPASS multicountry programme (Creating Opportunities through Mentoring, Parental Involvement and Safe Spaces)". In their last global report, drawing on an impact evaluation in Ethiopia, and evaluations in DRC and Pakistan, COMPASS finds that "As a result of participating in the program, girls had better knowledge of professional GBV services, felt more positive about themselves and about the future, and had stronger social networks and a safe space to go to". What worked well was continuous consultation with the girls "to ensure programming was responsive, flexible and addressed the needs of girls from diverse backgrounds", while "The existence of quality GBV services and trained staff was critical to ensure the safety and wellbeing of adolescent girls". (summarised by VAWG Helpdesk, 2020: 4).

- Reducing gender-based violence in conflict-affected communities in Cote d'Ivoire: An RCT found from mixed methods research during 2010-2012 that "Pairing a dialogue group that engages couples on household gender dynamics with an economic empowerment program for women was more effective in reducing intimate partner violence in conflict-affected communities in Cote d'Ivoire than the economic empowerment program alone." Key lessons learned included: engaging with both men and women is key, while programmes related to intimate partner violence should be "safe, appealing and culturally appropriate", and "consider identifying explicit strategies to address sexual violence". (Gupta et al., 2013, summarised by Green, 2014: unpaginated)

\subsection{Role of local organisations in humanitarian coordination and response}

In recent decades there is increasing recognition of the critical role of local organisations - such as local women-led organisations, women's rights organisations, organisations of people with disabilities, youth organisations - in achieving inclusive humanitarian action, including ensuring the rights of people marginalised by social inequalities and discrimination are upheld by humanitarian actors (Palmer et al., 2019; Call to Action, 2020; Robinson et al., 2020). There is less of a focus in the literature on humanitarian engagement with groups of older people, aside from engaging with "elders", which can be problematic as they are often elites whose experience does not reflect other older people's experiences (Robinson, et al., 2020: unpaginated; Barbelet, 2018: 31). There is recent growing awareness of the role of religious actors and faith groups in humanitarian response, who are "frequently core to local systems of response and resilience to crisis"20 (Wilkinson et al., 2016; Allouche et al., 2020: 19-20).

\footnotetext{
20 There are five evidence briefs on religious group's contributions to humanitarian response - see https://jliflc.com/world-humanitarian-summit-resources/ for full list. [Accessed 10 May 2021]
} 
There is guidance ${ }^{21}$ on organisations' effective participation but limited rigorous evidence on the effectiveness of interventions supporting their participation (as found for example by Robinson et al. (2020) for organisations of people with disabilities and older people). Moreover, there are challenges to establishing meaningful participation, and progress has been slow (ActionAid et al., 2020; Call to Action, 2020; Robinson et al., 2020; Lafrenière et al., 2019: 190; Sherwood \& Pearce, 2016). The 2020 the Inter-Agency Humanitarian Evaluation (IAHE) on Gender Equality and the Empowerment of Women and Girls - an independent mixed methods evaluation that included in-depth case studies and field research - reports that: (Bizzarri et al., 2020: x)

"A good practice observed in a few of the reviewed case studies to increase women's influence on decision making was to have women-led organizations and self-organizing women's groups more intentionally integrated into the response management and coordination structures. However, this practice was not observed with respect to any other marginalized group."

There is criticism that "two key frameworks for localization - the Grand Bargain and the Charter for Change - include few commitments to gender, and no guidance on how to support women led organizations" (Schaaf et al., 2020: 12). UN agencies and international non-governmental organisations continue to dominate humanitarian action, while local organisations led by and representing affected people tend to feel marginalised and lack access to sustainable funding that can support their longer-term engagement and capacity-building (Call to Action, 2020; 7; The Lutheran, 2018: 14). For example, organisations of people with disabilities report "facing physical, attitudinal, and institutional barriers to inclusion in decision-making processes, despite their desire to be more involved in humanitarian action" (Palmer et al., 2019: 21).

\section{Examples from the evidence of what has worked}

- Including organisations of people with disabilities and older people in humanitarian coordination in Pakistan, Nepal, Philippines, Jordan and Bangladesh: Age and Disability Task Forces (ADTF), which include age and disability actors, organisations of people with disabilities and older persons' associations, have been tried in these settings since 2010. The ADTFs undertake activities such as "advocacy and awareness raising; training UN, NGOs and government actors; development of technical guidance; input to response planning; improving identification of persons with disabilities and older people, services and referral mapping; increasing access to quality targeted services; and documenting barriers to accessing humanitarian assistance and sharing positive practices". "A common challenge is mobilizing sufficient resources for planning and administration and encouraging sufficient time commitment from members and coordinators." Key lessons are to engage with organisations of people with disabilities and older people before crisis; embed task forces in existing humanitarian coordination structures; and dedicate time and resources to sensitize humanitarian actors on disability and inclusion. (Palmer et al., 2019: 51-52)

\footnotetext{
${ }^{21}$ For example, the IASC Guidelines on Inclusion of Persons with Disabilities in Humanitarian Action "provide examples of actions that humanitarian actors should take to promote meaningful participation of persons with disabilities, including through their representative organizations" (Palmer et al., 2019: 21)

https://interagencystandingcommittee.org/iasc-task-team-inclusion-persons-disabilities-humanitarianaction/documents/iasc-guidelines [accessed 10 May 2021]
} 
- Church network humanitarian response in Myanmar: Partnered with Tearfund, the Myanmar Baptist Convention (MBC) - a network of nearly 5,000 churches operating in some of the country's most disaster-prone regions - "responds to small and large-scale humanitarian crises that impact the country every year. Being a widespread network, $\mathrm{MBC}$ is able to rapidly mobilise resources, trained staff and volunteers as emergencies occur. The strength of MBC's connections extends to other faith groups, local NGOs and the Government. At the village level, established committees involving churches and other civil society actors help to ensure effective coordination. Capacities were demonstrated following the 2015 monsoon floods that hit 12 out of 14 states, displacing 1.7 million people. The MBC network was able to reach over 100 affected communities to conduct emergency needs assessments within the first few hours of the floods, identify needs and distribute emergency food and non-food items." (Wilkinson et al., 2016: unpaginated)

\subsection{Inclusive peace processes}

Vernon (2019: 24) notes there are specific groups "whose engagement is essential for peace but who may otherwise be excluded", including "political, ethnic or geographically specific groups, women and youth, particular castes, sexual minorities, people suffering from violence-induced trauma, displaced people and refugees, and ex-combatants".

A recent rapid review found "a strong body of evidence on the role of women in peacebuilding and the strategies that women's rights advocates have taken to influence interventions in this area" (Birchall, 2020: 5). However, "while women participants and gender equality issues are increasingly present in peace processes and constitutional reform processes, more needs to be done to ensure that gender equality doesn't remain on the margins" (Birchall, 2020: 5-6). Birchall (2020: 5) summarises the areas where international actors may best be able to support and strengthen women's participation in such processes, including (among others): supporting women's collective action and applying multidimensional approaches that address both the practical and structural (political and power-based) constraints to women's voice, decisionmaking and leadership.

There is also growing interest in strengthening "the youth-inclusivity of peace processes"22, with awareness that their actual or perceived socio-economic and political exclusion leaves young people "particularly vulnerable to recruitment by armed groups", looking at the various contributions of young men and young women to prevent and recover from conflict (Vernon, 2019: 27; VAWG Helpdesk, 2020: 6; Aoki et al., 2019).

To date "very little attention has been paid to the meaningful participation of persons with disabilities in peacebuilding processes" (Close, 2021: 4). This rapid review also found little literature on the inclusion of older people or people with diverse sexual orientation, gender identity and/or expression, and sex characteristics in peace processes (Daigle \& Myrttinen, 2018).

\footnotetext{
22 See for example guidelines by IASC endorsed in 2020 - With us \& for us: working with and for young people in humanitarian and protracted crises https://interagencystandingcommittee.org/events/iasc-guidelines-workingand-young-people-humanitarian-and-protracted-crises [Accessed 14 May 2021]
} 
Meanwhile, faith-based actors' important contributions in contexts emerging from conflict are "important but underrecognised", with increasing interest from governments and international organisations (Shannahan \& Payne, 2016: 5; United States Institute of Peace (USIP), 2019). Shannahan and Payne (2016:5) note that "The range of peacebuilding activities that faith-based actors engage in is extensive, and includes mediation, humanitarian aid, and reconciliation and development work". They point out both the risk involved in "partnering with faith groups to address conflict and violence", and the "very significant lost opportunity cost to not doing so" (Shannahan \& Payne, 2016: 5). They highlight "The social and religious capital of some faithbased actors puts them in a position to help build sustainable peace, irrespective of whether or not the conflict has a religious component" (Shannahan \& Payne, 2016: 16). However, while there is considerable anecdotal evidence of the potential of faith-based organisations in peace processes, there is "a distinct lack of robust ... research to substantiate this and test assumptions in a scientific and reliable way" (Shannahan \& Payne, 2016: 18).

\section{Examples from the evidence of what has worked}

- Women mediators' network in Burundi: 'In 2015, a new nationwide network of women mediators, established by the UN in close partnership with the Ministry of Interior and civil society organisations, dealt with more than 3,000 local conflicts. Operating in groups of four mediators in 129 municipalities across the country, the network initiated dialogue between the authorities, security forces, political parties, protesters, civil society organisations and citizens." Among other activities, they "advocated for the release of demonstrators and opposition party members, sought to promote tolerance by advising on the constructive handling of political and electoral conflict, and countered rumours and fears with verifiable information". (Birchall, 2020: 17, citing Coomaraswamy, 2015: 55)

- Youth-led peacebuilding in the Central African Republic: A United Nations Peacebuilding Fund project (implemented by War Child UK, Conciliation Resources and two local partners from January 2019 to September 2020) provided young people with psychosocial support and life skills training; livelihoods training and economic empowerment support; conflict analysis, action planning and community outreach; and advocacy training and engagement with decision-makers. It provided opportunities for young people associated with armed groups and other vulnerable young people - groups that would not normally mix - to engage in discussion and dialogue. A final evaluation found the project was effective in supporting youth empowerment and youth participation in peacebuilding and advocacy, with an "improved understanding of peace and conflict, and strengthened relationships between young people and authorities and policymakers that are likely to outlast the project". However, the effectiveness of the livelihoods' component "was limited, due to delays, budget constraints and adaptations in design". Recommendations included incorporating a more gender-responsive approach to actively encourage the participation of young women, and a religious lens to address ChristianMuslim conflict divides. (Paaskesen \& Martial Ouakouma, 2020: 5, 8).

\section{Resilience}

Resilience refers to the ability of communities and households to endure stresses and shocks and adapt to changing circumstances without compromising their long-term prospects (OCHA, n.d.). This section focuses on humanitarian interventions to strengthen the resilience of people 
who experience heightened vulnerabilities in crises due to social inequalities and discrimination. It looks at evidence on what has worked for inclusion in 1) humanitarian preparedness and disaster risk reduction, and in programming in crisis contexts in 2) education and livelihoods, and 3) social protection.

\subsection{Inclusion in preparedness ${ }^{23}$ \& disaster risk reduction (DRR) ${ }^{24}$}

Looking at the evidence of inclusion of people with disabilities in this area, while there is growing awareness of the critical roles people with disabilities can play in preparedness and $\mathrm{DRR}^{25}$, they continue to be "routinely excluded" (Palmer et al., 2019: 7), with limited evidence on what has worked to include them. Robinson et al (2020) found no peer reviewed articles from 2010-2020 on building crisis resilience and preparedness for people with disability - and none for older people either. Twigg et al. (2018: 3) highlight emerging good practice, for example, "inclusive hospital preparedness plans, targeted cash transfers and training and sensitisation for staff on working with people with disabilities".

Traditional mental health and psychosocial support (MHPSS) in the humanitarian field has been focused on response and recovery; in the past decade there has been growing awareness of the benefits of integrating MHPSS programming with DRR interventions "to reduce risks of problematic mental health and psychosocial outcomes and to increase resilience to hazardous events" (Gray et al., 2021: 8; IASC, 2021: 7). The 2021 technical guidance note on this integration highlights that this involves consideration of 1) "inclusive approaches to building resilience in relation to the mental health and psychosocial needs and resources of particular groups, such as people with preexisting disabilities, women or children" and 2) "[inclusive DRR] practices for people with more profound mental health problems and psychosocial disabilities" (IASC, 2021: 14).

\section{Examples from the evidence of what has worked}

- Including people with disabilities in humanitarian preparedness and DRR in Bangladesh: Since 2009 the Centre for Disability in Development (a national NGO), working in partnership with CBM and another local NGO, has supported people with disabilities to cope with the effects of flooding and climate change. Activities include household targeted support for people with disabilities to access livelihood opportunities; register for state protection; counselling for preparedness' investment in preparing houses and protecting water supply; and establishing community self-help groups and

\footnotetext{
23 "Preparedness refers to the knowledge and capacities developed by governments, response and recovery organizations, communities and individuals to effectively anticipate, respond to and recover from the impacts of likely, imminent or current disasters. Preparedness is based on a sound analysis of disaster risks and good linkages with early warning systems ..." (Palmer et al., 2019: 7, bold added)

24 "Disaster risk reduction is aimed at preventing new and reducing existing disaster risk and managing residual risk, all of which contribute to strengthening resilience and therefore to the achievement of sustainable development." (Palmer et al., 2019: 7, bold added)

25 The 2015 Sendai Framework for Disaster Risk Reduction emphasises the importance of "the involvement of people with disabilities and their organisations in the design and implementation of disaster risk reduction (DRR) policies" (Twigg et al., 2018: 3), with IASC Guidelines on the inclusion of persons with disabilities in humanitarian action, 2019 setting out how to do this. https://interagencystandingcommittee.org/iasc-task-team-inclusionpersons-disabilities-humanitarian-action/documents/iasc-guidelines [Accessed 14 May 2021]
} 
community Disaster Management Committees. Communication materials were adapted, and training conducted in the local dialect. The community-based Disaster Management Committees proved to be "sustainable frameworks for the representation of people who are traditionally excluded from decision-making in government structures". (Palmer et al., 2019: 11, with full details of the project documented in Rothe et al., 2018)

- Integrating MHPSS into DRR in Bangladesh: In Dhaka, the international NGO, Action contre la Faim (ACF), partnered with the national government to mainstream MHPSS training and mental health awareness workshops in pre-existing government DRR initiatives in hazard-prone areas, training over 3,000 religious leaders, teachers, health and humanitarian workers, first responders and community members. (IASC, 2021: 2829)

\subsection{Inclusion in education \& livelihoods as part of crisis recovery and resilience to the next shock}

\section{Education}

Education is becoming more prominent in emergency response, especially in protracted refugee crises, with growing awareness its importance during crises ${ }^{26}$ (Cambridge Education, 2017). In a rigorous review of what works in education in emergencies, Burde et al. (2019) "identify significant growth in areas that include refugee education, girls' education, social-emotional learning, and tertiary education for conflict-affected populations; emerging research that includes protecting education from attack and 'preventing violent extremism'; and emerging trends that promise to focus on inclusive education for children with disabilities and early childhood development".

Looking specifically at education for girls in crisis settings, while the global evidence base on what works for girls' education is growing, there is "quite limited" evidence on the effectiveness of interventions "for the most disadvantaged girls (taking account of intersecting disadvantage)" with very few studies in conflict affected areas (Aslam, 2020: 6). Other reviews note a lack of evidence on what has worked for inclusion in education in emergencies for children with disabilities (Burde et al., 2019; Kuper et al., 2018), although there are case studies and guidance ${ }^{27}$.

A 2021 solutions book on how to keep girls learning in emergencies highlights promising practices, including for girls with disabilities (Guglielmi et al., 2021). It stresses that to improve school participation, "interventions must be sustainable, flexible, and create circumstances that enable new behaviours and norms. Involving girls and communities at the planning stage can allow their concerns and narratives to inform emergency response planning and help address the

\footnotetext{
${ }^{26}$ Education in crisis situations is recognised as being important for multiple reasons: 1) it provides "immediate physical, psychosocial and cognitive protection", with out-of-school children more vulnerable to protection risks; 2 ) it contributes to "individual, community and societal resilience" (combined with provision of "lifesaving skills, social and emotional learning, and psychosocial support"); 3) it is valued by communities, parents and children themselves. (European Commission, 2019: 4-5)

27 For example, UNICEF's 2018 guidance:

https://inee.org/system/files/resources/UNICEF_Education_English.pdfhttps://sites.unicef.org/disability/emergenci es/education.html [Accessed 14 May 2021]
} 
barriers that may be preventing girls from continuing in school during emergencies." (Guglielmi et al., 2021: 11)

Guglielmi et al. (2021: 15) analyses the evidence on how to strengthen gender-responsive distance education provision and learning outcomes, which has seen growing interest since the COVID-19 related school closures. They highlight the potential of distance education approaches to increase education access for children with disabilities and reach out-of-school children (Guglielmi et al., 2021: 17). They note that "In designing and implementing distance education, programmes must also account for the barriers that girls face in accessing this type of education. A gender-responsive remote learning curriculum will need to be at the core of distance learning, address gender norms often precluding girls from accessing education, and provide safe remote psychosocial support to girls" (Guglielmi et al., 2021: 15).

\section{Examples from the evidence of what has worked}

- Supporting girls' education in Kenya: The Kenya Equity in Education Project (KEEP) (implemented by World University Service Canada and Windle International Kenya with DFID funding of 18.3 million) aimed to support the education of girls aged 14-20 including refugees and female head of household in Northern Kenya. A network of 52 community mobilizers communicated with families and the wider community on the importance of girls' learning, while KEEP staff engaged with male religious and local political leaders, and trained role models, including young Kenyan refugee women who relocated to Canada to pursue higher education and returned to share their experiences. "At the project mid-point, there was already a $13 \%$ increase in parents who believed in the transformative power of education for girls." (Guglielmi et al., 2021: 11)

- Distance learning for refugee girls in Malawi: In response to COVID-19 school closures, the Jesuit Refugee Service, UNHCR, Plan International and Yetu Radio undertook a radio-based learning project to support primary, secondary and TVET education for 50 refugee and asylum-seeking girls living in Dzaleka refugee camp. Trained teachers used "different modes of distance learning, including radio, social media, and online platforms". Secondary level girls got smartphones and data bundles to continue their learning online, and a free and safe place to charge laptops and phones; primary and secondary level girls got radios, with lessons offered via radio. Ongoing listening sessions were held to understand the girls' challenges, needs and risks, and how these were affected by COVID-19, with support by social workers, psychosocial counselors and a Mother Group to mitigate the barriers the girls faced in continuing education. The Mother Group learnt about internet safety, conducted routine check-ins on girls' learning and well-being, distributed dignity kits and reinforced COVID-19 mitigation strategies. Not yet fully evaluated, the "intervention was able to provide continuity of learning for girl beneficiaries during the 7-month COVID-19 school closure" with all the girls returning to school when they reopened. (Guglielmi et al., 2021: 24)

\section{Livelihoods}

Support to livelihoods in humanitarian crises is seen as an area for growth by some donors, given increased protracted conflict, and unprecedented numbers of internally displaced people and refugees (Stites \& Bushby, 2017: 17). There are various interventions and strategies used in humanitarian settings: Young Lee (2014: 3) lists cash transfers, asset restoration (livestock, 
tools, equipment), agrarian interventions, training and placement programs, market interventions, enterprise development, village savings and loans associations and microfinance.

Cash transfers are increasingly popular with unconditional, multi-sectoral cash transfers thought to "offer greater flexibility for livelihood support" (Stites \& Bushby, 2017: 17; see Section 4.3 for further discussion of cash transfers). This rapid review found less literature on the inclusivity of other livelihoods interventions, although there is guidance on including people with disabilities and older people in livelihoods programming in emergencies ${ }^{28}$, and brief case studies. The literature on gender-sensitive livelihoods interventions in humanitarian contexts highlights how introducing resources through livelihood programmes can "attract internal and external threats" (Young Lee, 2014: 6). This research underlines that from the start gender and gender-based violence analysis is critical to judge any potential increase to vulnerabilities and exposure to threats and violence an intervention may trigger (Young Lee, 2014: 3). For example, interventions may inadvertently "Fuel conflict and violence within the household or community by changing gender norms and/or shifting balance of control over assets between men and women, or between generations" (Young Lee, 2014: 6).

\section{Examples from the evidence of what has worked}

- Livelihoods programming inclusive of people with disabilities in active conflict in the Middle East: Since 2016, Humanity \& Inclusion (HI) has provided technical support to a livelihoods consortium in an undisclosed Middle Eastern country to include a minimum $10 \%$ of beneficiaries with disabilities. The livelihood programming "includes three-month cycles of cash transfers, cash for work, vocational training, apprenticeships, small-business development, home agriculture and food production, and animal husbandry." HI supports the consortium to raise community awareness of the importance of inclusion of people with disabilities and older people in livelihood activities; provides training for consortium partners' staff; provides transport for people with disabilities to access vocational training; provides individualised case-management support; and conducted action research into the impact of integrating psychosocial support into a livelihoods programme. The intervention has found that "Fully disaggregating indicator targets by sex, age and disability facilitates the identification and targeting of persons with disabilities that are more at risk of exclusion". Most of the beneficiaries were working-age men with physical disabilities; more needed to be done to reach "older persons with disabilities, women with disabilities, and other underrepresented groups of persons with disabilities such as persons with psychosocial disabilities, persons with intellectual disabilities or persons with deaf-blindness". Another key lesson was that "Providing enough time is key to overcoming barriers relating to the attitudes of partners and the community and to reaching the many persons with disabilities whose eligibility for the activities can be limited by low levels of education and self-confidence". (Palmer et al., 2019: 47)

\footnotetext{
${ }^{28}$ For example, livelihoods inclusion standards are provided in Age and Disability Consortium (2018).
} 


\subsection{Inclusion in social protection (with a focus on cash transfers)}

Social protection is today "a critical strategy to reduce poverty, build resilience and enable development", and has been proven to enhance "the economic and productive capacity of even the poorest and most marginalized communities" (Winder Rossi et al., 2017: 4). One social protection instrument - cash transfer programming - has significantly increased in recent years in humanitarian responses.

In terms of how inclusive cash transfers tend to be, emerging evidence from governments' emergency cash transfers in response to the impacts of the COVID-19 pandemic suggests that these do not always include people facing heightened vulnerabilities during crises. A survey by HelpAge found that older men and women, across all countries surveyed ${ }^{29}$, faced significant challenges in accessing COVID-19 cash transfers. A particular challenge was the "lack of information and communication to older people, exacerbated by digital barriers", with older women particularly affected (Juergens \& Galvani, 2020). Moreover, a forthcoming study of cash transfers in six humanitarian responses ${ }^{30}$ (summarised in Brown \& Rothe, 2020) finds that for people with disabilities support alongside the cash transfer is needed to help overcome physical and institutional accessibility barriers. Brown and Rothe (2020) also highlight that the participation of people with disabilities and organisations of persons with disabilities in targeting can help mitigate the high risk of failing to identify eligible households with people with disabilities.

Looking at whether social protection can have positive outcomes for people facing social inequalities and discrimination during crises, two examples are 1) impacts on girls' learning and 2) impacts on women's empowerment.

Guglielmi et al. (2021: 44) find social protection can play an important role "in promoting continuity of learning" for girls during emergencies, making it essential that social protection systems are "designed with the capability to rapidly adapt and scale up to support existing and newly vulnerable children and adolescents in crisis contexts". Key strategies include contextrelevant vulnerability assessments to inform and adapt social protection interventions (e.g. robustly monitoring measures to support learners with disabilities); cash plus approaches to provide linkages to complementary services and referrals; and replacement school feeding interventions (provision of food baskets, food banks or community-provided meals) (Guglielmi et al., 2021: 44). They stress the need for more robust impact evaluations to test impact pathways given the "very limited evidence about the role of social protection in supporting improved learning outcomes in general, and especially in emergency contexts" (Guglielmi et al., 2021: 44).

The evidence on cash transfers and gender outcomes in crisis contexts is under-researched (Carter et al., 2019: 60). "A review of the evidence cites emerging mixed findings of cash relieving household tensions in humanitarian contexts and improving women's decision-making while also risking additional burdens being imposed on women and reinforcing gender

\footnotetext{
${ }^{29}$ HelpAge conducted the survey "in 17 countries: Peru, Paraguay, Colombia, Belize, India, Pakistan, Bangladesh, Philippines, Sri Lanka, Nepal, Vietnam, Myanmar, Mozambique, Tanzania, Ethiopia, Kenya and Malawi" (Juergens \& Galvani, 2020)

30 The study (Bodgener \& Rothe, forthcoming) looks at how inclusive cash transfer programmes were of people with disabilities in humanitarian responses in Pakistan, Bangladesh, Niger, Indonesia, Zimbabwe and the Philippines from 2014 to 2020.
} 
stereotypes" (Carter et al., 2019: 60, citing Simon, 2018). Cross et al. (2019: 26) note that cash transfers have the potential to put beneficiaries at risk "when they faced harassment and/or exploitation from gatekeepers and authorities related to collection"; therefore mitigation strategies are important to consider at programme design stage.

\section{Examples from the evidence of what has worked}

- Conditional cash transfer to support girls' education in Kenya: The Kenya Equity in Education Project (KEEP) conditional cash transfer to support up to 20,000 girls aged 1420 from refugee and female-headed households. Implemented by World University Service of Canada, UK aid-funded Girls Education Challenge, and Windle International School, targeting used a vulnerability index of "girls at risk of dropping out of school, orphans, child-headed households, protection issues and performance", with the cash transfer aiming "to reduce the financial barriers of regular school attendance and support transition to the next grade level". During COVID-19, "flexibility on cash disbursements was introduced to ensure continued support during lockdowns". An impact evaluation of 2,996 beneficiaries found improved attendance rates by $70 \%$, with a $90 \%$ transition rate to the next grade achieved. (Guglielmi et al, 2021: 39)

\section{Relief/services}

This section looks at inclusion in assistance and services provided in crises, focusing on three areas: inclusion in data and analysis for understanding needs and planning responses; inclusion in community engagement and community-based services; and targeted/specialised services.

\subsection{Inclusion in data and analysis for understanding needs and planning responses}

Inclusive data and analysis that responds to social inequalities and discrimination is critical for effective humanitarian action, and some guidance is available on how to do this ${ }^{31}$. Poor (not comparable or reliable) data or a lack of data, and a lack of systematic consultation with the affected people themselves to identify needs and support required, are major barriers to addressing humanitarian exclusion, and limits effective, needs-based programming for people facing specific, and intersecting, forms of discrimination (World Bank, 2020: 13; Humanity \& Inclusion, 2019; Boost et al., 2020). There are examples of successful inclusion informing humanitarian response; for example, in her review, Birchall (2020: 8) finds that "Gender-sensitive conflict analysis (GSCA) has been used successfully to engage communities in processes looking at the ways harmful gender norms fuel not just gender inequality but also conflict, broader discrimination, exclusion and violence." The 2020 Inter-Agency Humanitarian Evaluation on Gender Equality and the Empowerment of Women and Girls reports "progress in integrating [gender equality and the empowerment of women and girls] issues into IASC humanitarian

\footnotetext{
${ }^{31}$ For example the IASC Guidelines on Inclusion of Persons with Disabilities in Humanitarian Action, 2019 provide a complete overview of existing tools for collecting data on persons with disabilities in a humanitarian context. https://interagencystandingcommittee.org/iasc-task-team-inclusion-persons-disabilities-humanitarianaction/documents/iasc-guidelines [Accessed 14 May 2021]
} 
responses since 2017, especially in protracted crises", albeit still with limitations (Bizzarri et al., 2020: ix). The evaluation finds that: (Bizzarri et al., 2020: ix)

"humanitarian actors had more systematically consulted women and girls; improved in the collection and reporting of sex- and age-disaggregated data; made some progress in accounting for the needs of multiple populations and the specific needs of women and girls in needs assessment; and undertaken more nuanced analyses of gender-related gaps, inequalities and contextual factors in Humanitarian Response Plans".

This rapid review found more examples of a gender-inclusive approach to data and analysis to inform humanitarian responses, some on disability-inclusive data and analysis, and comparatively very little taking into account other drivers of marginalisation (age, religion and sexuality). Bizzarri et al. (2020: $x$ ) find improvements in consulting in needs assessment exercises with "youth and marginalized groups (for example, LGBTI people, persons with disabilities, the elderly and specific ethnic groups, among others)" but highlights that their "voices and needs of are still largely absent from decision making on humanitarian response".

\section{Examples from the evidence of what has worked}

- CARE Rapid Gender Analysis (RGA) approach and tool, Mozambique:32 developed by CARE during the humanitarian response in Syria in 2013, this rapid gender analysis has been used in over 50 crises $^{33}$. A global external evaluation looking at the period 2015-2020 found "strong evidence that the RGA approach has led to an increase in the availability of robust gender analysis and data on the different needs, roles, vulnerabilities and capabilities of women, girls, men, and boys", and consistent evidence that as a result new and existing interventions have been adapted to meets these needs. For example, immediately after the devastating Cyclone Idai in Mozambique in 2019, a RGA was conducted by CARE with a local organisation and shared with the emergency response consortium. The RGA found "lack of lighting in communities and accommodation/transit centres was of particular concern for women and adolescent girls", as was the loss of "social, business networks and participation in village savings and loans groups as a result of displacement". Based on the RGA recommendations, with funding donors and local partners, CARE distributed solar lights to households; installed lighting at schools, health services and latrines and water collection points; provided torches to women and girls; and established three safe spaces where women and girls could "meet, access psychosocial support, legal advice and report issues relating to GBV". (Huxtable \& Gillingham, 2020: 4-5, 26-27)

- Data collection on people with disabilities in humanitarian crises in Iraq, Jordan, Lebanon, South Sudan, Tonga, and Vanuatu: Palmer et al. (2019) provides a set of case studies that showcase how the Washington Group Questions ${ }^{34}$ can be used in

\footnotetext{
32 https://insights.careinternational.org.uk/in-practice/rapid-gender-analysis [Accessed 6 May 2021]

33 It is featured as good practice in the IASC Gender Handbook for Humanitarian Action, 2017 https://interagencystandingcommittee.org/iasc-reference-group-gender-and-humanitarian-action/iasc-genderhandbook-humanitarian-action-2017 [accessed 14 May 2021]

34 "The Washington Group Questions (WGQs) have been developed by the Washington Group on Disability Statistics, a group under the UN Statistical Commission, with the purpose of generating reliable and comparable data on persons with disabilities during national-level data collection exercises" (Palmer et al., 2019: 15).
} 
participatory research and rapid assessment studies on the situation of persons with disabilities during and after disasters, in internal-displacement and refugee contexts. The participation in assessments and research of people with disabilities and organisations of people with disabilities increased data accuracy and impact of the findings. It was key to train camp managers, enumerators and staff involved in monitoring and evaluation, programme managers and the organisations of people with disabilities on collecting, analysing and using disaggregated data. It was also important to ensure underrepresented groups were included in the data collection, such as women and girls, persons with intellectual and psychosocial disabilities, and persons with deafblindness. (Palmer et al., 2019: 15-16)

- Data collection and reparations for people with diverse sexual orientation, gender identity and/or expression, and sex characteristics, Colombia: A registry of victims of Colombia's 60-year internal armed conflict allows for disaggregated data, including identification of Lesbian Gay Bisexual Transgender Intersex (LGBTI) victims of human rights violations (most commonly, forced displacement, disappearance and sexual and gender-based violence). This has raised awareness of how the conflict and violence had affected LGBTI people and allowed for targeted assistance and reparations. A civil society organisation that works for gender equality that was targeted by armed groups became in 2019 the first Colombian CSO to receive reparations in the context of Colombia's transitional justice and peacebuilding efforts. (World Bank, 2020: 14)

- Intersectional inclusion analysis, Iraq: " $\mathrm{HI}$ is part of a consortium delivering an Australian government funded project, Building Peaceful Futures, aimed at supporting the return and reintegration of returnees, strengthening community resilience and social cohesion through inclusive services". HI helped the consortium explore "how disability, gender, age and diversity in the two project locations (Sinjar and Hawija) impact on access to services, decision-making structures and the realisation of basic human rights how disability, gender, age and diversity". Existing gender- and disability- sensitive analytical tools were adapted to incorporate contextual factors such as "faith, ethnic or tribal identity affiliation (actual or perceived), which intersect with gender, disability and age to create barriers to services, drive exclusion and discrimination". This new scope led to broader criteria for hiring enumerators "which directly enabled access to "difficult to reach' communities", and enabled the project to be aware of, and respond to, drivers of privilege and access, and avoid reinforcing social discrimination and societal cleavages (Brigden \& Ahluwalia, 2020: 10-11).

\subsection{Inclusion in community engagement and community-based services}

It is important that people affected by social inequalities and discrimination are included along with the rest of their communities. Guidance on inclusion in humanitarian action highlights a "twin-track approach" through mainstreaming inclusion by adapting humanitarian interventions to be accessible to all in the community, in addition to integrating specialised, targeted services that meet specific needs (Pearce, 2014: 2). This is not always achieved in crisis settings (and development interventions more generally): for example, women, children and older persons with disabilities are particularly vulnerable to gender-based violence in displaced settings but they face difficulty accessing support and services (Pearce, 2014: 4). 
Looking at what works to prevent violence against women and girls in conflict and humanitarian crises, Murphy et al. (2019: 26) note that

"A common thread across successful programmes appears be an 'all-of-community' approach, even when more specialised (school, faith leaders, etc.) delivery mechanisms are used. Nevertheless, even within these community-level approaches, it is important that these programmes are centred on women and girls and designed in a way to ensure accountability to them (for example, creating feedback mechanisms for women and girls, having women and girls co-lead programme design, ensuring women and girls are empowered to take up leadership positions in the programme)."

\section{Examples from the evidence of what has worked}

- Including women and girls in water, sanitation and hygiene facility in Cox's Bazar, Bangladesh: Water, sanitation and hygiene (WASH) planning and design in humanitarian camps has tended to be dominated by male architects and engineers "often with gendered assumptions about the user". With the rapid formation of huge refugee camps in Cox's Bazar, Bangladesh, feedback from women and girls highlighted "significant challenges around access, safety, privacy, and dignity, including management of personal hygiene and menstruation". An Oxfam pilot project worked with Rohingya women and adolescent girls, and female architects to improve the WASH facilities: an independent evaluation (with a control group) is planned and will assess the impact of this intervention. Undertaken prior to completion of the project, a qualitative study found this experience confirms "consultation with users about their needs is vital to ensure the full use of facilities and minimise harmful outcomes". (Farrington (2019: 295).

- Including people with disabilities in gender-based violence services in conflictaffected communities in Burundi, Ethiopia, Jordan and the Northern Caucasus in the Russian Federation: This project on building capacity for disability inclusion in gender-based violence programming in humanitarian settings was undertaken by the International Rescue Committee (IRC) and the Women's Refugee Commission. A 2015 qualitative study identified positive practices from the intervention. It found that following capacity-building support, "GBV practitioners reported a positive change in their attitudes toward working with persons with disabilities, particularly as a result of the experiential and reflective learning activities in the project" and "GBV practitioners also learned to better tailor their services to survivors with disabilities - including through home visits, home-based activities and specialized case management services with more effective and appropriate communications approaches." Another key finding was that women with disabilities and caregivers who were supported to join local village savings and loans groups (VSLAs) enabled them to develop robust peer networks, leading "to information exchange and skills building, improved self-esteem". They also "reported increased independence and decision-making and greater respect and status within the family and community as a result of their newfound access to income-earning opportunities". The findings from the multi-country study were used to inform an IRC toolkit on gender-based violence and disability for gender-based violence practitioners ${ }^{35}$. (Pearce, 2015: 2)

\footnotetext{
35 https://reliefweb.int/sites/reliefweb.int/files/resources/GBV-disability-Toolkit-all-in-one-book.pdf (Accessed 6
} May 2021) 
- Faith sensitive approach to psychosocial support services to refugees from Darfur, Chad: HIAS Chad has started to involve faith leaders in their community-based psychosocial support services to refugees from Darfur, for whom "Islamic faith is a fundamental part of their identity and culture". HIAS Chad reports consulting with faith leaders, building relationships, and exploring together ways to work together to provide psychosocial support. HIAS staff have provided training to faith leaders on sexual and gender-based violence and psychosocial issues, while faith leaders have provided training to HIAS staff to increase their understanding of the Islamic faith. The case study concludes that "It takes time to build the kind of relationships necessary for a true partnership, but HIAS Chad has found that the engagement of faith leaders in their community mobilisation and support activities has already significantly increased their effectiveness." (The Lutheran World Federation \& Islamic Relief Worldwide, 2018: 47-48)

\subsection{Targeted/specialised services}

The literature highlights that, while there are specialised services during crises that aim to support people affected by social inequalities and discrimination, the overall context is one of gaps in provision, funding constraints, and limited research on the effectiveness of these interventions. To give a few examples: Robinson et al. (2020) find that most services for people with disabilities in humanitarian response are health-focused, with a lack of focus on ensuring people with disabilities have access to other services. Bourassa and Murphy (2020: 28) highlight that access to, and quality of, GBV-related services tend to be low across different humanitarian settings, with "the lack of funding and the overstretched capacity of the sector affects the prioritisation and provision of services". Singh et al (2018) call for more and better research on the effectiveness of sexual and reproductive health interventions ${ }^{36}$ in humanitarian crises, in particular on abortion care, female genital mutilation and adolescent girls with disabilities and adolescent girls with diverse sexual orientations and gender identities (summarised by VAWG Helpdesk, 2020: 4). Chynoweth (2019: 1) points out the few services targeting men, boys and people with diverse sexual orientation, gender identity and/or expression, and sex characteristics who are survivors of gender-based violence perpetrated against refugees and migrants along the central Mediterranean route.

However, systematic reviews and other analyses identify proven and emerging good practices from the implementation of a variety of services in crises that target people affected by social inequalities and discrimination. Some examples are given below.

\section{Examples from the evidence of what has worked}

- Mobile and remote gender-based violence service delivery in Myanmar, Iraq and Burundi: From 2016 the International Rescue Committee (IRC) ${ }^{37}$ developed and

\footnotetext{
36 There are guidelines for sexual and reproductive services in humanitarian and conflict-affected contexts. VAWG Helpdesk (2020: 4) lists "the Inter-Agency Field Manual (IAFM) for Reproductive Health in Humanitarian Settings (chapter on adolescent SRH); Adolescent Sexual and Reproductive Health Toolkit for Humanitarian Settings; IRC Guidelines for Mobile and Remote Gender-Based Violence (GBV) Service Delivery ...; and new guidance developed on Menstrual Hygiene Management (MHM) by the Research for Health in Humanitarian Crises (R2HC) programme."

${ }^{37}$ With the support of U.S. Bureau of Population, Refugee and Migration Services (PRM) and the European Civil Protection and Humanitarian Aid Operations (ECHO).
} 
piloted tools, platforms and programme guidance ${ }^{38}$ in Myanmar, Iraq and Burundi to provide gender-based violence services to women and girls in hard-to-access humanitarian settings. Interventions included group psychosocial support, life skills activities, and confidential entry points (including hotlines) for gender-based violence survivors' case management services. In 2017-2018 an independent mixed methods evaluation found key success factors included psychosocial support to decrease the stigma for seeking help; confidentiality and safety for both beneficiaries and staff involved in gender-based violence services; and community focal points to facilitate access. Challenges with the hotline services included "limited access to phones, poor internet/phone service, and negative or mixed cultural reactions to women and girls' phone/internet use". (James et al., 2018: 5)

- Gender-based violence services for refugee/migrant men and boys on the central Mediterranean route to Italy: "On the Aquarius search and rescue vessel in the Mediterranean, MSF health providers raised awareness about sexual violence against men and boys and available services through convening private groups of 10 to 15 men and adolescent boys who spoke the same language." Health personnel provided the group with information on sexual violence and its "medical and psychological consequences that can be treated or managed", explaining "that free, confidential medical care was available on the ship". Consequently "the proportion of men/boy survivors who came forward for medical care increased from 3 percent in 2017 to 33 percent in 2018". (Chynoweth, 2019: 52)

- Supporting trans women refugees in Lebanon: In 2016, the Women's Refugee Commission and MOSAIC piloted a project to support the safety and well-being of Iraqi, Syrian, Palestinian, and Lebanese trans women living in Beirut. The project created a safe space to meet, bond, and provide information on services. A social worker facilitated art and drama therapy group sessions. Participants felt "a strengthened sense of community and belonging", while the enhanced peer network, "helped with sharing information about physical safety and security, accessing resources, and engaging in advocacy and community-building". (WRC, 2021: 26)

\footnotetext{
38 https://reliefweb.int/report/world/guidelines-mobile-and-remote-gender-based-violence-gbv-service-delivery-
} enmy [Accessed 6 May 2021] 


\section{References}

ActionAid. (2012). Strategies for success. Access to Justice for Women. https://actionaid.org/publications/2012/strategies-success-access-justice-women

ActionAid et al. (2020). Humanitarian Funding, Partnerships and Coordination in the COVID-19 crisis: Perspectives from local women-led organisations and women's rights organisations. https://charter4change.files.wordpress.com/2020/07/wlo-covid19-joint-policy-brief.pdf

Age and Disability Consortium. (2018). Humanitarian inclusion standards for older people and people with disabilities. CBM International, Bensheim, HelpAge International, London, and Handicap International, Lyon. https://humanityinclusion.org.uk/sn_uploads/document/humanitarian-inclusion-standards-for-older-peopleand-people-with-disabilities-ADCAP.pdf

Akerkar, S., \& Bhardwaj, R. (2018). Good practice guide: embedding inclusion of older people and people with disabilities in humanitarian policy and practice. Oxford: Oxford Brookes University. http://www.helpage.org/download/5abce47081d9f

Allouche, J., Hoffler, H., \& Lind, J. (2020). Humanitarianism and Religious Inequalities: Addressing a Blind Spot. Coalition for Religious Equality and Inclusive Development. (CREID) Working Paper Volume 2020, Number 04. Brighton, Institute of Development Studies.

https://opendocs.ids.ac.uk/opendocs/bitstream/handle/20.500.12413/15718/CREID_Worki ng_Paper_4.pdf? sequence $=1 \&$ isAllowed $=\mathrm{y}$

Ashton, C. (2013). Preventing inter-religious violence in Plateau State Nigeria: Final program evaluation. Search for Common Ground, Nigeria. https://www.sfcg.org/wpcontent/uploads/2014/07/NGR_EV_-Preventing-Violence-in-Plateau-StateEvaluation_FINAL-2013_names-removed.pdf

Aslam, M., Gordon, R., Rawal, S., Rose, P., \& Watson, J. (2020). Girls' Education Challenge Research Feasibility Study. Report for DFID. REAL Centre, University of Cambridge. https://www.educ.cam.ac.uk/centres/real/publications/GEC_Research_Feasibility_Scoping _Report_final_upload.pdf

Barbelet, V. (2018). Older people in displacement: falling through the cracks of emergency responses. ODI. https://odi.org/en/publications/older-people-in-displacement-fallingthrough-the-cracks-of-emergency-responses/

Barbelet, V., \& Wake, C. (2020). Inclusion and exclusion in humanitarian action. The state of play. HPG Working Group. Overseas Development Institute.

https://www.odi.org/sites/odi.org.uk/files/resource-documents/inclusion_lit_review_web.pdf

Birchall, J. (2020). Gender-sensitive security and justice interventions in Sub-Saharan Africa, MENA and South Asia. K4D Helpdesk Report 932. Brighton, UK: Institute of Development Studies.

https://opendocs.ids.ac.uk/opendocs/bitstream/handle/20.500.12413/15888/932_Gender_s ensitive_security_and_justice_interventions.pdf?sequence $=1$ \&isAllowed=y

Bizzarri, M., Cano Vinas, M., Khogali, H., \& Jantzi, T. (2020). The Inter-Agency Humanitarian Evaluation (IAHE) on Gender Equality and the Empowerment of Women and Girls (GEEWG), 2020. https://interagencystandingcommittee.org/system/files/202101/The\%20InterAgency\%20Humanitarian\%20Evaluation\%20\%28IAHE\%29\%20on\%20Gender\%20Equalit 
y\%20and\%20the\%20Empowerment\%20of\%20Women\%20and\%20Girls\%20\%28GEEWG $\% 29-$ Report.pdf

Bodgener, P., \& Rothe, M. (forthcoming). Disability Inclusive Cash Assistance. Learnings from Practice in Humanitarian Response.

Boost, E., Jones, N., \& Kwauk, C. (2020). Life skills for adolescent girls in the COVID-19 pandemic. Girls' Education Challenge, GAGE and Brookings Institute. https://dfid-gecapi.s3.amazonaws.com/production/assets/51/GEC_Guidance_Note_Life_Skills_and_COVI D-19_July_2020.pdf

Brigden, S., \& Ahluwalia, K. (2020). Towards more inclusive practices: A Disability, Gender and Age Intersectional Resource. Lyon/Paris: Humanity \& Inclusion/F3E.

https://hi.org/sn_uploads/document/2020-

HI_DisabilityGenderAgelntersectionality_GN09.pdf

Brown, D., \& Rothe, M. (2020). Making cash inclusive in humanitarian responses. DevPolicyBlog. https://devpolicy.org/making-cash-inclusive-in-humanitarian-responses-20200423-2/

Burde, D., Lahmann, H., \& Thompson, N. (2019). Education in emergencies: 'What works' revisited. Education and Conflict Review, 2, 81-88.

https://discovery.ucl.ac.uk/id/eprint/10081593/1/Burde_Article_14_Burde.pdf

Call to Action (2020). Call to Action on Protection from Gender-based Violence in Emergencies. Road Map 2021-2025. https://1ac32146-ecc0-406e-be7d-

301d317d8317.filesusr.com/ugd/1b9009_e8c2214a8950412cbd82599e6c08b110.pdf

Cambridge Education. (2017). Education in Emergencies Guidance Note. https://www.dai.com/uploads/EiE_Guidance_Note-8fc7f4.pdf

Carter, B. (2021). Impact of social inequalities and discrimination on vulnerability to crises. K4D Helpdesk Report 994. Brighton, UK: Institute of Development Studies. https://doi.org/10.19088/K4D.2021.049

Carter, B., Roelen, K., Enfield S., \& Avis, W. (2019). Social Protection Topic Guide. Revised Edition. K4D Emerging Issues Report. Brighton, UK: Institute of Development Studies. https://opendocs.ids.ac.uk/opendocs/bitstream/handle/20.500.12413/14885/Social_Protecti on_Topic_Guide_online.pdf?sequence=1\&isAllowed=y

Chynoweth, S. (2019). "More Than One Million Pains": Sexual Violence Against Men and Boys on the Central Mediterranean Route to Italy. New York, NY: Women's Refugee Commission. https://reliefweb.int/sites/reliefweb.int/files/resources/Libya-Italy-Report-032019.pdf

Chynoweth, S. K., Zwi, A. B., \& Whelan, A. K. (2018). Socializing accountability in humanitarian settings: a proposed framework. World Development, 109, 149-162.

https://doi.org/10.1016/j.worlddev.2018.04.012

Close, S. (2021). Untapped peacebuilders: Including persons with disabilities in building peace. London: Conciliation Resources. https://rc-services-assets.s3.eu-west1.amazonaws.com/s3fspublic/Untapped_peacebuilders_including_persons_with_disabilities_in_building_peace.pd f

Combaz, E., \& Mcloughlin, C., (2014). Voice, Empowerment and Accountability: Topic Guide. Birmingham, UK: GSDRC, University of Birmingham. https://gsdrc.org/wpcontent/uploads/2015/07/GSDRC_VEA_topic_guide.pdf 
Coomaraswamy, R. (2015). Preventing Conflict, transforming justice, securing the peace. A Global Study on the Implementation of United Nations Security Council Resolution 1325. UN Women. https://wps.unwomen.org/pdf/en/GlobalStudy_EN_Web.pdf

Corboz, J., Siddiq, W., Hemat, O., Chirwa, E.D., \& Jewkes, R. (2019). What works to prevent violence against children in Afghanistan? Findings of an interrupted time series evaluation of a schoolbased peace education and community social norms change intervention in Afghanistan. PLoS ONE 14(8): e0220614. https://doi.org/10.1371/journal.pone.022061

Cross, A., Manell, T., \& Megevand, M. (2018). Humanitarian Cash Transfer Programming and Gender-based Violence Outcomes: Evidence and Future Research Priorities. Women's Refugee Commission and International Rescue Committee. https://reliefweb.int/sites/reliefweb.int/files/resources/genderandctpwrcirc.pdf

Daigle, M., \& Myrttinen, H. (2018). Bringing diverse sexual orientation and gender identity (SOGI) into peacebuilding policy and practice. Gender \& Development, 26(1), 103-120. https://doi.org/10.1080/13552074.2018.1429091

DCAF - Geneva Centre for Security Sector Governance, Organization for Security and Cooperation in Europe (OSCE)/ Office for Democratic Institutions and Human Rights (ODIHR), \& UN Women. (2019a). "Security Sector Governance, Security Sector Reform and Gender", in Gender and Security Toolkit. Geneva: DCAF, OSCE/ODIHR, UN Women. https://www.osce.org/files/f/documents/1/1/440834_0.pdf

DCAF, OSCE/ODIHR, \& UN Women. (2019b). "Justice and Gender", in Gender and Security Toolkit. Geneva: DCAF, OSCE/ODIHR, UN Women. https://www.dcaf.ch/sites/default/files/publications/documents/GSToolkit_Tool4\%20EN\%20FINAL_1.pdf

European Commission. (2019). Education in Emergencies in EU-funded Humanitarian Aid Operations. DG ECHO Thematic Policy Document no 10.

https://ec.europa.eu/echo/files/news/eie_in_humanitarian_assistance.pdf

Farrington, M. (2019) Social and feminist design in emergency contexts: the Women's Social Architecture Project, Cox's Bazar, Bangladesh. Gender \& Development, 27:2, 295-315, https://doi.org/10.1080/13552074.2019.1626593

Flynn, E., Moloney, C., Fiala-Butora, J., \& Echevarria, V. (2019). Final Report: Access to Justice of Persons with Disabilities. Galway: Centre for Disability Law and Policy, National University of Ireland, Galway.

Glass, N., Perrin, N., Marsh, M., Clough, A., Desgroppes, A., Kaburu, F., Ross, B., \& ReadHamilton, S. (2019). Effectiveness of the Communities Care programme on change in social norms associated with gender-based violence (GBV) with residents in intervention compared with control districts in Mogadishu, Somalia. BMJ Open, 9(3), e023819. https://doi.org/10.1136/bmjopen-2018-023819

Gray, B., Eaton, J., Christy, J., Duncan, J., Hanna, F., \& Kasi, S. (2021). A proactive approach: Examples for integrating disaster risk reduction and mental health and psychosocial support programming. International journal of disaster risk reduction, 54, 102051.

Green, S. (2014). Economic and Social Empowerment to Reduce Violence against Women. Research Brief. International Rescue Committee. https://gbvresponders.org/wpcontent/uploads/2014/07/EAE-Research-Brief-Jan-2014.pdf 
Guglielmi, S., Jones, N., Nicolai, S., Pereznieto, P., Plank, G., Vu, N., Sanchez-Tapia, I., \& Mackintosh, A. (2021). Reimagining Girls' Education: Solutions to Keep Girls Learning in Emergencies. New York: UNICEF.

https://inee.org/system/files/resources/Reimagining\%20Girls\%20Education\%20Solutions\% 20to\%20Keep\%20Girls\%20Learning\%20in\%20Emergencies\%20.pdf

Gupta, J., Falb, K.L., Lehmann, H., Kpebo, D., Xuan, Z., Hossain, M., Zimmerman, C., Watts, C., \& Annan, J. (2013). Gender norms and economic empowerment intervention to reduce intimate partner violence against women in rural Côte d'Ivoire: a randomized controlled pilot study. BMC International Health and Human Rights, 13: 46.

Haider, H. (2016). International humanitarian law and peace processes (GSDRC Helpdesk Research Report 1399). Birmingham, UK: GSDRC, University of Birmingham. https://gsdrc.org/wp-content/uploads/2016/09/HDQ1399.pdf

Hald, M., Mårtendal, J., \& Smith, S., with input from Grzywnowicz, M. (2021). Realising Inclusivity. The role of the United Nations in promoting inclusion at the country level. Uppsala, Sweden: Dag Hammarskjöld Foundation. https://www.daghammarskjold.se/wpcontent/uploads/2021/03/realising-inclusivity.pdf

Holden, J., Lee, H., Martineau-Searle, L., \& Kett, M. (2019). Disability Inclusion in Humanitarian Programming. Disability Inclusion Helpdesk Research Report No. 9. London, UK: Disability Inclusion Helpdesk.

Humanity \& Inclusion. (2019). Data on Persons with Disabilities in Humanitarian Action. Collecting quantitative data with the Washington Group Questions. Key findings and Recommendations. https://humanity-inclusion.org.uk/sn_uploads/document/2019-05-dataon-persons-with-disabilities-in-humanitarian-action-key-findings-and-recommendations.pdf

Huxtable, J., \& Gillingham, S. (2020). When time won't wait. CARE'S Rapid Gender Analysis Approach External Evaluation. https://insights.careinternational.org.uk/images/inpractice/RGA-and-measurement/GiE_Learning_RGA_Full-Report_When-Time-WontWait_External-Evaluation_August2020.pdf

Inter-Agency Standing Committee. (2015). Guidelines for Integrating Gender-Based Violence Interventions in Humanitarian Action: Reducing risk, promoting resilience and aiding recovery. https://gbvguidelines.org/wp/wp-content/uploads/2015/09/2015-IASC-Genderbased-Violence-Guidelines_lo-res.pdf

Inter-Agency Standing Committee. (2016). Policy. Protection In Humanitarian Action. https://interagencystandingcommittee.org/system/files/202011/IASC\%20Policy\%20on\%20Protection\%20in\%20Humanitarian\%20Action\%2C\%202016. pdf

Inter-Agency Standing Committee. (2017). Policy. Gender equality and the empowerment of women and girls in humanitarian action.

https://interagencystandingcommittee.org/system/files/2020-

11/IASC\%20Policy\%20on\%20Gender\%20Equality\%20and\%20the\%20Empowerment\%20 of\%20Women\%20and\%20Girls\%20in\%20Humanitarian\%20Action.pdf

Inter-Agency Standing Committee. (2021). Technical Note linking disaster risk reduction (DRR) and mental health and psychosocial support (MHPSS). Practical Tools, Approaches and Case Studies. Inter-Agency Standing Committee.

https://interagencystandingcommittee.org/iasc-reference-group-mental-health-andpsychosocial-support-emergency-settings/technical-note-linking-disaster-risk-reduction-drrand-mental-health-and-psychosocial-support-mhpss 
Jackson, P., Bell, J., \& Bakrania, S. (2019). Security and justice evidence mapping update. GSDRC, International Development Department, University of Birmingham. https://assets.publishing.service.gov.uk/media/5d19e429e5274a08cc5c29c9/S_and_J_evi dence_map_update_June_2019___FINAL_250619_.pdf

James, L. E., Welton-Mitchell, C., Laird, B., Neiman A., \& O'Connor, M. (2018). Feasibility and acceptability study of the IRC's mobile and remote GBV service delivery in Myanmar, Burundi and Iraq. The International Rescue Committee. https://reliefweb.int/sites/reliefweb.int/files/resources/GBV-Mobile-and-Remote-GBVService-Delivery_-Full-Research-Report.pdf

Juergens, F., \& Galvani, F. (2021). Social protection for older people during COVID-19 and beyond. SPACE Social Protection Approaches to COVID-19: Expert advice helpline, and HelpAge International. Published by DFID and GIZ.

https://socialprotection.org/sites/default/files/publications_files/Social\%20protection\%20for \%20older\%20people\%20during\%20COVID-19.pdf

Kuper, H., Saran, A., White, H., Kumar, S. T., Tolin, L., Muthuvel, T., \& Wapling, L. (2018). Rapid evidence assessment (REA) of what works to improve educational outcomes for people with disabilities in low-and middle-income countries. International Centre for Evidence in Disability, London School of Hygiene and Campbell Collaboration.

Lafrenière, J., Sweetman, C., \& Thylin, T. (2019). Introduction: gender, humanitarian action and crisis response. Gender \& Development, 27(2), 187-201. https://doi.org/10.1080/13552074.2019.1634332

Megevand, M., \& Marchesini, L. (2020). Women and girls safe spaces: a toolkit for advancing women's and girls' empowerment in humanitarian settings international rescue committee and international medical corps. International Rescue Committee (IRC) and International Medical Corps. https://reliefweb.int/sites/reliefweb.int/files/resources/IRC-WGSS-ToolkitEng.pdf

Murphy, M., \& Bourassa, A. (2021). Gap Analysis of Gender-Based Violence in Humanitarian Settings: a Global Consultation. London: Elrha. https://www.elrha.org/wpcontent/uploads/2021/02/Elrha_GapAnalysis_GBV_Accessible_PDF_2021.pdf

Murphy, M., Hess, T., Casey, J., \& Minchew, H. (2019). What works to prevent violence against women and girls in conflict and humanitarian crisis - Synthesis Brief. Washington DC and London: International Rescue Committee, Global Women's Institute and the https://www.rescueuk.org/sites/default/files/document/2051/p868ircsynthesisbriefreportlr.pdf

OCHA (n.d.). Position paper. Resilience.

https://cerf.un.org/sites/default/files/resources/OCHA\%20Position\%20Paper\%20Resilience $\% 20 F I N A L . p d f$

Office of the High Commissioner for Human Rights (OHCHR) \& United Nations High Commissioner for Refugees (UNHCR) (2013). The Protection of Human Rights in Humanitarian Crises. A Joint Background Paper by OHCHR and UNHCR IASC Principals, 8 May 2013.

https://www.globalprotectioncluster.org/_assets/files/tools_and_guidance/human_rights_pr otection/OHCHR-UNHCR\%20Joint\%20Paper_EN.pdf

Office of the United Nations High Commissioner for Human Rights (OHCHR) \& Center for Economic and Social Rights (CESR), (2013). Who will be accountable? Human Rights and the Post-2015 Development Agenda. Office of the United Nations High Commissioner for 
Human Rights (OHCHR) and Center for Economic and Social Rights (CESR). https://www.sdg16hub.org/system/files/2019-

07/Who\%20Will\%20Be\%20Accountable\%20POLICY\%20DOCUMENT.pdf

Ortoleva, S., Bjerregaard, A., \& Beaulieu, C. (2019). Submission to the Special Rapporteur on the Rights of Persons with Disabilities: Good Practices for Increasing Effective Access to Justice for Women and Girls with Disabilities. Women Enabled International.

https://www.womenenabled.org/pdfs/WEl\%20Access\%20to\%20Justice\%20Good\%20Pract ices\%20Submission\%20to\%20UN\%20Special\%20Rapporteur\%20on\%20Persons\%20with \%20Disabilities,\%20Aug\%209,\%202019.pdf

Paaskesen, L., \& Martial Ouakouma, T. (2020). Final evaluation of the 'Alternatives to Violence: Strengthening Youth-Led Peacebuilding in the Central African Republic' project. https://www.un.org/peacebuilding/sites/www.un.org.peacebuilding/files/documents/alternati ves_to_violence_final_evaluation_final_version.pdf

Palmer, T., Bertozzi, E., Dominik, G., \& Pettey, E. (2019). Case studies collection 2019. Inclusion of persons with disabilities in humanitarian action. 39 examples of field practices, and learnings from 20 countries, for all phases of humanitarian response. CBM International, Humanity \& Inclusion (HI), and the International Disability Alliance (IDA).

https://reliefweb.int/sites/reliefweb.int/files/resources/Case\%20studies_Inclusion\%20of\%20 persons\%20with\%20disabilities\%20in\%20humanitarian\%20action_CBM_HI_IDA.pdf

Pearce, E. (2014). Disability inclusion: Translating policy into practice in humanitarian action. New York, NY: Women's Refugee Commission.

https://www.womensrefugeecommission.org/wp-content/uploads/2020/04/DisabilityInclusion-Translating-Policy-into-Practice-in-Humanitarian-Action.pdf

Pearce, E. (2015). I See That it Is Possible": Building Capacity for Disability Inclusion in Genderbased Violence Programming in Humanitarian Settings. New York, NY: Women's Refugee Commission and International Rescue Committee.

http://www.womensrefugeecommission.org/wp-content/uploads/2020/04/DisabilityInclusion-in-GBV-English.pdf

Pearce, E., Paik, K., \& Robles, O.J. (2016). Adolescent Girls with Disabilities in Humanitarian Settings: "I Am Not 'Worthless'-I Am a Girl with a Lot to Share and Offer". Girlhood Studies, 9:1, 118-136. http://dx.doi.org/10.3167/ghs.2016.090109

Perrin, N., Marsh, M., Kaburu, F., Poulton, C., \& Glass, N. (n.d.). Sustained Effectiveness of the Communities Care Program to Change Social Norms about Gender-based Violence in Somalia and South Sudan.

https://svri.org/forums/forum2019/Presentations/Sustained\%20Effectiveness\%20Perrin.pdf

Petrie, C. (2012). Report of the Secretary-General's Internal Review Panel on United Nations Action in Sri Lanka.

https://digitallibrary.un.org/search?f1=author\&as=1\&sf=title\&so=a\&rm=\&m1=e\&p1=UN.+S ecretary-General\&ln=en

Robinson. A, Marella. M., \& Logam. L (2020). Gap Analysis: the Inclusion of People with Disability and Older People in Humanitarian Response. London: Elrha.

https://www.elrha.org/wp-content/uploads/2020/07/Elrha-HIF_Gap-Analysis_Inclusion-ofpeople-with-disability-and-older-people_Literature-Review2020-A.pdf

Robles, O. J. (2014). I'm Here: Adolescent Girls in Emergencies Approach and tools for improved response. New York: Women's Refugee Commission.

https://reliefweb.int/sites/reliefweb.int/files/resources/I-m-Here-report-FINAL.pdf 
Rothe, M., Brown, D., \& Neuschäfer, O. (2018). Saving lives and leaving no one behind: The Gaibandha Model for disability-inclusive disaster risk reduction. CBM. https://www.cbm.org/fileadmin/user_upload/DRR_Booklet_FINAL_-_Online_10MB.pdf

Ryan, G., lemmi, V., Hanna, F., Loryman, H., \& Eaton, J. (2019). Mental Health for Sustainable Development: A Topic Guide for Development Professionals. K4D Emerging Issues Report. London and Brighton, UK: Mental Health Innovation Network and IDS

Saran, A., White, H., \& Kuper, H. (2020). Evidence and gap map of studies assessing the effectiveness of interventions for people with disabilities in low-and middle-income countries. Campbell Systematic Reviews, 16(1), e1070. https://doi.org/10.1002/cl2.1070

Schaaf, M., Boydell, V., Sheff, M. C., Kay, C., Torabi, F., \& Khosla, R. (2020). Accountability strategies for sexual and reproductive health and reproductive rights in humanitarian settings: a scoping review. Conflict and health, 14, 1-18. https://doi.org/10.1186/s13031020-00264-2

Shannahan, C., \& Payne, L. (2016). Faith-based Interventions in Peace, Conflict and Violence: A Scoping Study. Centre for Trust, Peace and Social Relations, Coventry University. https://jliflc.com/wp-content/uploads/2016/05/JLI-Peace-Conflict-Scoping-Paper-May2016.pdf

Sherwood, E., \& Pearce, E. (2016). "Working to Improve Our Own Futures": Inclusion of Women and Girls with Disabilities in Humanitarian Action. New York, NY: Women's Refugee Commission. https://www.womensrefugeecommission.org/wpcontent/uploads/2020/04/Strengthening-Networks-of-Women-with-Disabilities.pdf

Simon, C. A. (2018). Setting the stage: What we know (and don't know) about the effects of cash-based interventions on gender outcomes in humanitarian settings. In Cash Learning Partnership "Collected papers on gender and cash transfer programmes in humanitarian contexts". https://www.unwomen.org//media/headquarters/attachments/sections/library/publications/2019/discussion-papereffect-of-cash-based-interventions-on-gender-outcomes-en.pdf?la=en\&vs=4519

Singh N.S., Smith J., Aryasinghe S., Khosla R., Say L., \& Blanchet, K. (2018). Evaluating the effectiveness of sexual and reproductive health services during humanitarian crises: A systematic review. PLoS ONE 13(7): e0199300. https://doi.org/10.1371/journal.pone.0199300

Stites, E., \& Bushby, K. (2017). Livelihood strategies and interventions in fragile and conflictaffected areas: assessing trends and changes from 2012 to 2016. Secure Livelihoods Research Consortium. London: Overseas Development Institute (ODI). https://securelivelihoods.org/wp-content/uploads/7.-Livelihood-strategies-andinterventions-in-fragile-and-conflict-affected-areas_-2012-to-2016.pdf

The Lutheran World Federation \& Islamic Relief Worldwide. (2018). A faith-sensitive approach in humanitarian response: Guidance on mental health and psychosocial programming. Geneva and Birmingham: LWF and IRW. https://interagencystandingcommittee.org/system/files/faithsensitive_humanitarian_response_2018.pdf

Twigg, J., Lovell, E., \& Kett, M. (2018). Disability inclusion and disaster risk reduction: Overcoming barriers to progress. Briefing Note. London: Overseas Development Institute. https://covid19.alnap.org/system/files/content/resource/files/main/12324.pdf 
UN Women, UNDP, UNODC, \& OHCHR. (2018). A practitioner's toolkit on women's access to justice programming. Module 1: The theory and practice of women's access to justice programming. UN Women, UNDP, UNODC and OHCHR https://www.ohchr.org/Documents/Publications/PractitionerToolkit/WA2J_Module1.pdf

United States Institute of Peace. (2019). USIP's Work on Religious Engagement in Peacebuilding. Washington D.C.: United States Institute of Peace. https://www.usip.org/publications/2019/07/religious-engagement-peacebuilding

Vernon, P. (2019). Local peacebuilding. What works and why. Peace Direct and Alliance for Peacebuilding. https://peaceinsight-whatworks.s3.eu-central-1.amazonaws.com/pd-localpeacebuilding-report-v2.pdf

Wilkinson, O., Ager, A., Ingram, T., Boan, D., \& Asai, N. (2016). Engaging local faith communities for sustainable capacity for prevention and response. Evidence Brief 4. Evidence for the Religious Groups' Contribution to Humanitarian Response. World Humanitarian Summit 2016. Joint Learning Initiative on Faith and Local Communities. https://jliflc.com/wpcontent/uploads/2016/05/WHS_JLIFLC_Evidence-Brief_4-ONLINE-1.pdf

Winder Rossi, N., Spano, F., Sabates-Wheeler, R., \& Kohnstamm, S. (2017). Social Protection and Resilience. Supporting livelihoods in protracted crises, fragile and humanitarian context. FAO Position Paper. Rome, Food and Agriculture Organization of the United Nations. Institute for Development Studies. http://www.fao.org/3/i7606e/i7606e.pdf

Women's Refugee Commission. (2015). Including Adolescent Girls with Disabilities in Humanitarian Programs: Principles and Guidelines. New York, NY: Women's Refugee Commission. https://www.womensrefugeecommission.org/wpcontent/uploads/2020/04/Girls-w-Disabilities-Principles-Guidelines.pdf

Women's Refugee Commission. (2021). Addressing Sexual Violence against Men, Boys, and LGBTIQ+ Persons in Humanitarian Settings. A Field-Friendly Guidance Note by Sector. New York, NY: Women's Refugee Commission.

https://www.womensrefugeecommission.org/wp-content/uploads/2021/02/AddressingSexual-Violence-against-Men-Boys-LGBTIQ-Persons-Guidance-Note-022021-1.pdf

World Bank. (2020). Sexual Orientation and Gender Identity in Contexts Affected by Fragility, Conflict, and Violence. Washington D.C.: World Bank.

https://openknowledge.worldbank.org/bitstream/handle/10986/33722/Sexual-Orientationand-Gender-Identity-in-Contexts-Affected-by-Fragility-Conflict-and-Violence-DiscussionPaper.pdf?sequence=1\&isAllowed=y

Young Lee, A. (2014). A Double-edged Sword: Livelihoods in Emergencies Guidance and Tools for Improved Programming. New York, NY: Women's Refugee Commission.

https://reliefweb.int/sites/reliefweb.int/files/resources/A-Double-edged-Sword-Livelihoodsin-Emergencies-web.pdf 


\section{Acknowledgements}

We thank the following experts who voluntarily provided suggestions for relevant literature or other advice to the author to support the preparation of this report. The content of the report does not necessarily reflect the opinions of any of the experts consulted.

- $\quad$ Brigitte Rohwerder, Institute of Development Studies

- Jo Howard, Institute of Development Studies

- Manuel Rothe, CBM Global

\section{Suggested citation}

Carter, B. (2021). Inclusion in crisis response, recovery and resilience. K4D Helpdesk Report. Institute of Development Studies. DOI: 10.19088/K4D.2021.079.

\section{About this report}

This report is based on nine days of desk-based research. The K4D research helpdesk provides rapid syntheses of a selection of recent relevant literature and international expert thinking in response to specific questions relating to international development. For any enquiries, contact helpdesk@k4d.info.

K4D services are provided by a consortium of leading organisations working in international development, led by the Institute of Development Studies (IDS), with the Education Development Trust, Itad, University of Leeds Nuffield Centre for International Health and Development, Liverpool School of Tropical Medicine (LSTM), University of Birmingham International Development Department (IDD) and the University of Manchester Humanitarian and Conflict Response Institute (HCRI).

This report was prepared for the UK Government's Foreign, Commonwealth \& Development Office (FCDO) and its partners in support of pro-poor programmes. Except where otherwise stated, it is licensed for non-commercial purposes under the terms of the Open Government Licence v3.0. K4D cannot be held responsible for errors or any consequences arising from the use of information contained in this report. Any views and opinions expressed do not necessarily reflect those of FCDO, K4D or any other contributing organisation.

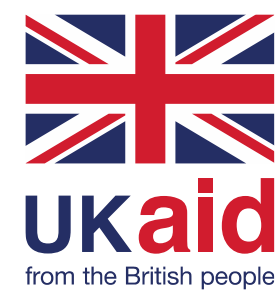

(C) Crown copyright 2021. 